\title{
A retrospective study of various factors affecting infertility in Rajasthan, India
}

\author{
Preksha T. Singh ${ }^{1 *}$, Saroj Choudhary ${ }^{2}$, Shreyans D. Singhvi ${ }^{1}$
}

\begin{abstract}
${ }^{1}$ Department of Obstetrics and Gynecology, NHL Municipal Medical College, Ahmedabad, Gujarat, India
${ }^{2}$ Department of Obstetrics and Gynecology, S. N. Medical College, Jodhpur, Rajasthan, India
\end{abstract}

Received: 04 May 2020

Accepted: 30 May 2020

\author{
*Correspondence: \\ Dr. Preksha T. Singh, \\ E-mail: prekshasingh@icloud.com
}

Copyright: (c) the author(s), publisher and licensee Medip Academy. This is an open-access article distributed under the terms of the Creative Commons Attribution Non-Commercial License, which permits unrestricted non-commercial use, distribution, and reproduction in any medium, provided the original work is properly cited.

\begin{abstract}
Background: Infertility is seen fairly common in these days and it cause not only reproductive but also psychological impairment of the parents. Infertility leads to multitude of personal as well as societal repercussions. There are various advances in technology which help the parents suffering from infertility. Infertility is defined as the failure to conceive after one year of regular intercourse in women $<35$ years not using contraception and after six months in women $>35$ years.

Methods: A retrospective study of 400 females and their husbands' coming to the department of gynecology, Umaid Hospital, Jodhpur, Rajasthan was undertaken from February 2020 to March 2020. A structural self-constructed questionnaire was used in the study. A well-informed verbal consent was taken by the participants of the study. It had open and closed ended questions. Further, an ultrasound sonography (USG) was performed to check the reproductive organs of the patient, to find the cause of infertility, as well as biochemical examination on male sperm, was performed to find out the sperm abnormality, ejection disorders and other long-term illness.

Results: In our study, we found multiple factors affecting infertility issues in females. These factors were- menstrual cycle abnormally, bleeding abnormality and years of active married life. We also found Polycystic ovarian disorder as a major underlying cause of female infertility and sperm abnormality as a major cause of male infertility.

Conclusions: Authors recommend frequent female routine checkups to asses early case of infertility and treat it as early as possible.
\end{abstract}

Keywords: Endocrine, Female, Infertility

\section{INTRODUCTION}

Infertility is seen fairly common in these days and it cause not only reproductive but also psychological impairment of the parents. Infertility leads to multitude of personal as well as societal repercussions. There are various advances in technology which help the parents suffering from infertility. Infertility is defined as the failure to conceive after one year of regular intercourse in women $<35$ years not using contraception and after six months in women >35 years. ${ }^{1}$ Some authors and clinicians distinguish sub-fertility from infertility, the latter may be seen as a synonym of sterility, defined as the absolute inability to conceive (absence of sperm, premature menopause or complete tubal obstruction). ${ }^{2}$ Epidemiological data suggest that about $10-15 \%$ of all couples will experience difficulties to conceive (primary infertility) or to conceive the number of children they wanted (secondary infertility). ${ }^{2,3}$

According to the World Health Organization (WHO), in developed countries, female infertility accounts for $37 \%$ of infertile couples, male infertility for $8 \%$ and both male and female infertility in $35 \%$. Five percent of couples had unexplained infertility and $15 \%$ became pregnant during the study conducted by WHO. 
In this study, authors have studied various demographic aspects of female patients and found multiple factors accounting to infertility.

\section{METHODS}

A retrospective study of 400 females and their husbands' coming to the department of gynecology, Umaid Hospital, Jodhpur, Rajasthan was undertaken from February 2020 to March 2020.

\section{Inclusion criteria}

- Females in their reproductive age group, who were not pregnant and gave a valid verbal consent for participation in the study.

\section{Exclusion criteria}

- Females not in their reproductive age group, who were pregnant and did not provide a valid verbal consent for the study.

A structural self-constructed questionnaire was used in the study. A well-informed verbal consent was taken by the participants of the study. It had open and closed ended questions. Further, an Ultrasound Sonography (USG) was performed to check the reproductive organs of the patient, to find the cause of infertility, as well as biochemical examination on male sperm, was performed to find out the sperm abnormality, ejection disorders and other long-term illness.

\section{Statistical analysis}

The sampling technique used was purposive. The data was compiled and analyzed using Google spreadsheets. To find the association between different factors- the statistical method of Chi-square test and $\mathrm{p}$ value was taken. A null hypothesis was formed with no association taken into consideration and Chi-square values and pvalue was calculated to find the possible association between the decided factors. The confidence interval taken for $\mathrm{p}$-value is $90 \%$ with 0.01 level of significance. Values corresponding $<0.01$ are found significant, the null hypothesis stands void and the factors are found to be associated for $99 \%$ confidence level.

\section{RESULTS}

The study included 400 females of reproductive age group (average 30 years) from Umaid hospital, Jodhpur, India which included both new cases and follow up cases. Thorough history of the patient was undertaken and multiple factors were studied. The first factor studied was the female educational status (Table 1).

The next factor studied was menstrual cycle length. 277 patients reported for normal menstrual cycle while, 123 patients reported of abnormal menstrual cycle history; abnormal cycle included- short, long and irregular menstrual cycle (Table 2).

Table 1: Distribution of educational status of the females.

\begin{tabular}{|ll|}
\hline Educational status & Number of females \\
\hline Illiterate & 28 \\
\hline Just literate & 2 \\
\hline Primary education & 28 \\
\hline Secondary education & 66 \\
\hline Higher education & 94 \\
\hline Graduate & 182 \\
\hline Total & 400 \\
\hline
\end{tabular}

Table 2: Distribution of menstrual cycle history of the females.

\begin{tabular}{|lll|}
\hline Menstrual cycle & $\begin{array}{l}\text { Number of } \\
\text { females }\end{array}$ & Percentage \\
\hline Normal & 277 & $69.25 \%$ \\
\hline Irregular/abnormal & 123 & $30.75 \%$ \\
\hline Total & 400 & $100 \%$ \\
\hline
\end{tabular}

Table 3: Distribution of bleeding history in the patients.

\begin{tabular}{|lll|}
\hline Bleeding history & Number of patients & Percentage \\
\hline Mild & 121 & $30.25 \%$ \\
\hline Moderate & 243 & $60.75 \%$ \\
\hline Heavy & 36 & $9 \%$ \\
\hline Total & 400 & $100 \%$ \\
\hline
\end{tabular}

The next factor studied was severity of bleeding. Out of 400 patient $243(60.75 \%)$ patient have moderate bleeding (Table 3).

Table 4: Distribution of years of active married life in the patients.

\begin{tabular}{|lll|}
\hline $\begin{array}{l}\text { Years of active } \\
\text { married life }\end{array}$ & $\begin{array}{l}\text { Number of } \\
\text { females }\end{array}$ & Percentage \\
\hline 1- 5 years & 192 & $48 \%$ \\
\hline 6-10 years & 135 & $33.75 \%$ \\
\hline 11-15 years & 54 & $13.5 \%$ \\
\hline 16-20 years & 12 & $3 \%$ \\
\hline 21-25 years & 5 & $1.25 \%$ \\
\hline 26-30 years & 2 & $0.5 \%$ \\
\hline Total & 400 & $100 \%$ \\
\hline
\end{tabular}

The next factor studied was years of active married life of the females. From all cases, most of the patients have active married life of the duration of 1 to 10 year (Table 4).

The next factor studied was infertility type found in the clinic. Primary infertility is the one of the females bearing no child in the past while secondary infertility is the of 
the female carrying one or more child in the past. Amongst all patients, most (343) had no child $\left(1^{\circ}\right.$ infertility), while some (57) patients had one or more than one child ( $2^{\circ}$ infertility) (Table 5$)$.

Table 5: Distribution of type of infertility in the patients.

\begin{tabular}{|l|l|l|}
\hline Type of infertility & $\begin{array}{l}\text { Number of } \\
\text { females }\end{array}$ & Percentage \\
\hline Primary infertility & 343 & $85.75 \%$ \\
\hline Secondary infertility & 57 & $14.25 \%$ \\
\hline Total & 400 & $100 \%$ \\
\hline
\end{tabular}

Table 6: Distribution of addiction history in the patients.

\begin{tabular}{|lll|}
\hline Addiction history & $\begin{array}{l}\text { Number of } \\
\text { females }\end{array}$ & Percentage \\
\hline No addiction history & 256 & $64 \%$ \\
\hline Tobacco addiction & 90 & $22.5 \%$ \\
\hline Alcohol addiction & 17 & $4.25 \%$ \\
\hline Gutka addiction & 17 & $4.25 \%$ \\
\hline Masala addiction & 20 & $5 \%$ \\
\hline Total & 400 & $100 \%$ \\
\hline
\end{tabular}

The next factor studied was addiction history of the female. Out of 400 patients highest (256) patients had no addiction and 144 patients had an addiction history. In patients with addiction history 68 patients had tobacco addiction (Table 6).

Further, female and male causes of infertility were studied. In female causes, polycystic ovarian syndrome lead to infertility issues in $32.5 \%$ of the females; which indicated as a major underlying cause of infertility. Others include ovarian factors other than PCOS and unexplained and miscellaneous factors (Table 7).

Table 7: Causes of female infertility in the patients of the study.

\begin{tabular}{|lll|}
\hline $\begin{array}{l}\text { Causes of female } \\
\text { infertility }\end{array}$ & $\begin{array}{l}\text { Number of } \\
\text { females }\end{array}$ & Percentage \\
\hline PCOS & 72 & $32.5 \%$ \\
\hline Uterine & 60 & $26.25 \%$ \\
\hline Tubal & 13 & $8 \%$ \\
\hline Others & 38 & $17.25 \%$ \\
\hline Total & 400 & $100 \%$ \\
\hline
\end{tabular}

From all 400 patients, total 75 patients have male infertility cause, from which highest cause is sperm abnormality $(17.5 \%)$ and lowest are ejaculation disorder $(0.25 \%)$ (Table 8$)$.

Further, association between various factors and infertility were studied. The first factor studied was association between menstrual cycle abnormality and infertility (Table 9).
Table 8: Causes of male infertility in the patients of the study.

\begin{tabular}{|ll|l|}
\hline $\begin{array}{l}\text { Causes of male } \\
\text { infertility }\end{array}$ & $\begin{array}{l}\text { Number } \\
\text { of males }\end{array}$ & \begin{tabular}{l} 
Percentage \\
\hline Sperm abnormality
\end{tabular} \\
\hline Ejacuation disorder & 1 & $90.33 \%$ \\
\hline Other long-term illness & 4 & $1.33 \%$ \\
\hline Total & & $5.33 \%$ \\
\hline
\end{tabular}

Table 9: Association between menstrual cycle history and infertility.

\begin{tabular}{|lll|}
\hline Menstrual cycle & $\begin{array}{l}\text { Fertile } \\
\text { females }\end{array}$ & $\begin{array}{l}\text { Infertile } \\
\text { females }\end{array}$ \\
\hline Normal & 186 & 91 \\
\hline Irregular/abnormal & 46 & 97 \\
\hline Total & 212 & 188 \\
\hline
\end{tabular}

A null hypothesis was formed indicating no association between menstrual cycle abnormality and infertility was formed, after statistical analysis, Chi-square test found was -46.6728 and the p-value found was $<0.0000001$. As, p-value found was $<0.1$, the null hypothesis stands void and there is a positive association between menstrual cycle abnormality and infertility found.

Table 10: Association between bleeding history and infertility.

\begin{tabular}{|lll|}
\hline Bleeding history & Fertile females & Infertile females \\
\hline Mild & 49 & 72 \\
\hline Moderate & 152 & 91 \\
\hline Heavy & 11 & 25 \\
\hline Total & 212 & 188 \\
\hline
\end{tabular}

Table 11: Association between years of active married life and infertility.

\begin{tabular}{|lll|}
\hline $\begin{array}{l}\text { Years of active } \\
\text { married life }\end{array}$ & Fertile females & Infertile females \\
\hline 1- 5 years & 114 & 78 \\
\hline 6-10 years & 81 & 54 \\
\hline 11-15 years & 12 & 42 \\
\hline 16-20 years & 4 & 8 \\
\hline 21-25 years & 1 & 4 \\
\hline 26-30 years & 0 & 2 \\
\hline Total & 212 & 188 \\
\hline
\end{tabular}

Further, association between bleeding during menstruation and infertility studied (Table 10).

A null hypothesis was formed indicating no association between bleeding during menstruation and infertility was formed, after statistical analysis, Chi-square test found was 23.7747 and the p-value found was 0.000006877 . As, p-value found was $<0.1$, the null hypothesis stands void 
and there is a positive association between bleeding during menstruation and infertility found.

The next associative factor studied was years of active married life and infertility (Table 11).

A null hypothesis was formed indicating no association between years of active married life and infertility was formed, after statistical analysis, Chi-square test found was 32.6275 and the p-value found was 0.000004462 . As, p-value found was $<0.1$, the null hypothesis stands void and there is a positive association between years of active married life and infertility found.

\section{DISCUSSION}

In this study, we found multiple factors affecting infertility issues in females. These factors weremenstrual cycle abnormally, bleeding abnormality and years of active married life (Table 12).

Table 12: Association of multiple factors affecting infertility.

\begin{tabular}{|c|c|c|c|c|c|c|}
\hline \multirow{2}{*}{ Variable } & & \multicolumn{2}{|l|}{ Fertility } & \multirow{2}{*}{$\begin{array}{l}\text { Chi-square } \\
\text { value }\end{array}$} & \multirow{2}{*}{ p-value } & \multirow{2}{*}{ Association } \\
\hline & & Fertile females & Infertile females & & & \\
\hline \multirow{6}{*}{$\begin{array}{l}\text { Years of } \\
\text { active } \\
\text { married life }\end{array}$} & $1-5$ years & 114 & 78 & \multirow{6}{*}{32.6275} & \multirow{6}{*}{0.000004462} & \multirow{6}{*}{ Yes } \\
\hline & $6-10$ years & 81 & 54 & & & \\
\hline & $11-15$ years & 12 & 42 & & & \\
\hline & $16-20$ years & 4 & 8 & & & \\
\hline & $21-25$ years & 1 & 4 & & & \\
\hline & $26-30$ years & 0 & 2 & & & \\
\hline \multirow{2}{*}{$\begin{array}{l}\text { Menstrual } \\
\text { cycle }\end{array}$} & Normal & 186 & 91 & \multirow{2}{*}{ 46. I 6728} & \multirow{2}{*}{$<0.00000001$} & \multirow{2}{*}{ Yes } \\
\hline & Abnormal & 46 & 97 & & & \\
\hline \multirow{3}{*}{$\begin{array}{l}\text { Bleeding } \\
\text { history }\end{array}$} & Mild & 49 & 72 & \multirow{3}{*}{23.7747} & \multirow{3}{*}{0.000004462} & \multirow{3}{*}{ Yes } \\
\hline & Moderate & 152 & 91 & & & \\
\hline & Heavy & 11 & 25 & & & \\
\hline
\end{tabular}

Authors have also found polycystic ovarian disorder as an underlying cause of infertility in females. PCOS is a disorder growing commonly these days. It is very common in females, while there is no such similar condition found in males. Currently, 'Rotterdam criteria' are the most popular for defining this disorder. ${ }^{4}$

PCOS is diagnosed when at least two of the three following clinical findings are present: oligo-or anovulation, clinical or biochemical signs of hyperandrogenism and polycystic ovaries on ultrasound or direct inspection. The ultrasound criteria to define polycystic ovaries are the presence of 12 or more subcapsular ovarian cysts with a diameter of less than 10 $\mathrm{mm}$ or an increase in the ovarian volume of more than 10 $\mathrm{ml} .{ }^{5}$ Using the newer 'Rotterdam criteria', the prevalence of PCOS may be as high as $18 \%$ in a community-based population. ${ }^{6}$ In women with oligomenorrhea or hirsutism, the reported prevalence was respectively $87 \%$ and $92 \% .^{7}$

Although women with hirsutism and/or hyperandrogenemia and with polycystic ovaries on ultrasound, i.e. PCOS according to the 'Rotterdam criteria', can have regular menstrual cycles, and $60 \%$ of PCOS women are reported to be fertile, the condition is associated to a higher risk of reproductive failure. ${ }^{8,9}$ This is not only because of oligo-oranovulation but also because they have an increased risk for preterm labor, preeclampsia, and gestational diabetes. ${ }^{10}$

The first-line treatment for infertility because of PCOS should focus on weight reduction since $90 \%$ of infertile women with PCOS are overweight and obesity independently contributes to infertility. Exercise and diet programs conceived for PCOS women are highly costefficient in overcoming infertility because a weight loss of $5-10 \%$ may restore a regular menstrual. ${ }^{11}$

Many endocrine disorders, can lead to female infertility by interacting and impairing the normal reproductive ovarian function. These endocrine disorders should be excluded in women with ovarian causes of infertility, without neglecting the other causes of female infertility, such as tubal disorders, obstructions of the genital tract and endometriosis. Data in literature on the prevalence of infertility in women with chronic endocrine disorders are however scarce and observational studies in this area should clarify this issue. Some of these abnormalities are "subclinical". A thorough history, clinical examination and biological evaluation will orient the clinician in his or her differential diagnosis. Infertility diagnosis needs a multidisciplinary approach in which the endocrine aspects play a key role in the work-up to detect a particular endocrine disorder. ${ }^{12}$ 


\section{ACKNOWLEDGMENTS}

Authors would like to thank the patients who participated in the study and help us frame the study.

Funding: No funding sources Conflict of interest: None declared

Ethical approval: Not required

\section{REFERENCES}

1. Practice Committee of the American Society for Reproductive Medicine. Definitions of infertility and recurrent pregnancy loss. Fertil Steril. 2008;90:S60.

2. Evers JLH. Female subfertility. Lancet. 2002;360:151-9.

3. Thonneau P, Marchand S, Tallec A, Ferial ML, Ducot B, Lansac J, et al. Incidence and main causes of infertility in a resident population (1 850000$)$ of three French regions (1988-1989). Human Reprod. 1991;6(6):811-6.

4. Revised 2003 consensus on diagnostic criteria and long-term health risks related to polycystic ovary syndrome (PCOS). Rotterdam ESHRE/ASRMSponsored PCOS consensus workshop group. Human Reprod. 2004;19:41-7.

5. Balen AH, Laven JS, Tan SL, Dewailly D. Ultrasound assessment of the polycystic ovary: international consensus definitions. Human Reprod Update. 2003;9:505-14.

6. March WA, Moore VM, Willson KJ, Phillips DI, Norman RJ, Davies MJ. The prevalence of polycystic ovary syndrome in a community sample assessed under contrasting diagnostic criteria. Human Reprod. 2010;25:544-51.

7. Adams J, Polson DW, Franks S. Prevalence of polycystic ovaries in women with anovulation and idiopathic hirsutism. Br Med J. 1986;293:355-9.

8. Carmina E, Lobo RA. Polycystic ovaries in hirsute women with normal menses. Am J Med. 2001;111:602-6.

9. Brassard M, AinMelk Y, Baillargeon JP. Basic infertility including polycystic ovary syndrome. Med Clin North Am. 2008;92:1163-92.

10. Legro RS. Pregnancy considerations in women with polycystic ovary syndrome. Clin Obster Gynecol. 2007;50:295-304.

11. Clark AM, Thornley B, Tomlinson L, Galletley C, Norman RJ. Weight loss in obese infertile women results in improvement in reproductive outcome for all forms of fertility treatment. Human Reprod. 1998; 13:1502-5.

12. Unuane D, Tournaye H, Velkeniers B, Poppe K. Endocrine disorders and female infertility. Best Pract Res Clin Endocrinol Metabol. 2011;25(6):861-73.

Cite this article as: Singh PT, Choudhary S, Singhvi SD. A retrospective study of various factors affecting infertility in Rajasthan, India. Int J Reprod Contracept Obstet Gynecol 2020;9:2910-4. 